\title{
ПРОБЛЕМА СУПЕРІНФЕКЦІЙ: СВІТОВА ЗАГРОЗА СМЕРТІ ЧИ МОЖЛИВОСТІ ЇЇ ГЛОБАЛЬНОГО ПОДОЛАННЯ?
}

\author{
Тернопільський національний медичний університет ім. І.Я. Горбачевського
}

За даними ВООЗ, у 2017 р. 10,4 млн осіб захворіли на туберкульоз, 47 \% хворих були інфріковані збудниками з множинною медикаментозною стійкістю до антимікобактерійних препаратів, а 1,7 млн з них померли. Щороку фріксують до 700 тис. випадків смерті від інфрекційних захворювань у пульмонології: ХОЗЛ, бронхіальної астми, атипової пневмонії та інтерстиційних захворювань легень. Генералізовані септичні інфекціі з нагноєннями коронавіруси викликають мутації мікроорганізмів до антибактерійних препаратів та фрормують стійкість до медикаментів.

Мета дослідження - покращити ранню діагностику резистентного туберкульозу та перервати шляхи їі фрормування за допомогою молекулярно-технологічних методів.

Огляд даних доводить необхідність покращення ранньої діагностики суперінфекцій, яка дасть змогу запобігти фрормуванню розширеної стійкості мікроорганізмів до антибактерійних препаратів. Велика швидкість утворення резистентності бактерій нині випереджає впровадження нових протимікробних препаратів, що становить загрозу старіючому населенню планети. Через фрормування резистентності мікроорганізмів, змішаної специфрічної та неспецифрічної фрлори до основних препаратів у світі спостерігається поява глобальних захворювань, зумовлених «супербактерією - жахливою бактерією - superbug». Через низький рівень сучасної молекулярної діагностики цей рівень «суперінфекцій» є прихованим, а зареєстрована кількість суттєво занижена. За відсутності ефективних глобальних кроків, спрямованих на зменшування швидкості фоормування резистентності мікроорганізмів, до 2050 р. кількість населення планети може зменшуватися по 10 млн осіб на рік через реактивацію атипових пневмоній, вторинного туберкульозу (ТБ), розширення тотального резистентного туберкульозу (XXDR).

Висновки. Впровадження сучасних молекулярногенетичних технологій дозволить з високою точністю встановити етіологію процесу, провести видову ідентифрікацію мікобактерій та мікроорганізмів і визначити френотипну та генотипну чутливість бактерій до антимікобактерійних препаратів. Така діагностика сприятиме ефективному лікуванню пацієнтів, які вже заражені стійкими штамами бактерій.

Ключові слова: суперінфекція, туберкульоз, мікобактерія, антимікобактерійні препарати, абсолютна резистентність.

За даними ВООЗ, туберкульоз є однією з 10-ти провідних причин смертності у світі. Зокрема у 2017 р. на ТБ захворіли 10,4 млн пацієнтів, 1,7 млн померло, в т.ч. 0,4 млн з ВІЛ-іноекцією. Від загального числа випадків 64 \% припадає на сім країн, серед яких Індія, Індонезія, Китай, Нігерія, Пакистан, Філіпіни, Південна Африка. У цьому ж році 1,0 млн дітей захворіли на туберкульоз, а 250 тис. померли від нього, враховуючи дітей з коінфекцією ТБ/ВІЛ. За оцінками ВООЗ, 600 тис. пацієнтів з вперше діагностованим туберкульозом мали стійкість до рифампіцину, з яких у 500 тис. випадків було виявлено мультирезистентний туберкульоз. Незважаючи на покращення показників виявлення туберкульозу, ситуація в Україні залишається складною і навіть прогностично несприятливою [1]. 25,0 \% дітей до 1 року, які померли, свідчить про приховану епідемію та пізнє виявлення задавнених форм генералізованого туберкульозу. Причому 33,0 \% таких осіб помирає вдома. Згідно з когортним аналізом (аналітико-статистичний довідник 20072017 рр.), вилікувано 27,1 \%, лікування завершене у 48,9 \%, померло - 9,4 \% хворих. Отже неефективним виявляється лікування хворих на вперше діагностований туберкульоз у 25,0 \% випадків, на рецидивний ТБ - у 34,9 \%, на мультирезистентний ТБ - у 54,0 \%. Така низька ефективність лікування хворих негативно впливає на епідемічну ситуацію в Україні, що загрожує розвитком мікобактерій, які будуть набувати тотальну стійкість до антимікобактерійних препаратів (XXDR), появу так званої «супертуберкульозної інсрекції» [1, 2].

За даними керівника Центру з контролю і профрілактики захворювань (CDC, США) Т. Фрідена, бактерії, які 
резистентні до всіх препаратів, називаються супербактеріями, а через їх поширення людство ризикує опинитися в постантибіотичному світі [3]. Іншими словами, якщо супербактерії завоюють світ, то світова спільнота опиниться без антимікробних препаратів.

Суперіноекція є закономірним етапом інволюції бактерій. Ще у 1928 р. О. Флемінг випадково підмітив, що вирощені ним у пробірці гриби можуть пригнічувати ріст бактерій. 3 того часу історія людства суттєво змінилася таким чином, що винайдений ним антибіотик пеніцилін продовжує випускатися і захищатися $\beta$-лактамними кільцями та досі рятувати мільйони пацієнтів. До синтезу пеніциліну 100 \% хворих помирало від дистерії, пневмоній, сифрілісу та післяопераційних інфекційних ускладнень. Антибіотики стали потужною зброєю людства від інсрекцій.

Зараз ідентифріковано 50 видів мікобактерій, рід нараховує 200 видів, які розділені на 4 категорії залежно від кольору колоній та швидкості росту. Важливою ознакою патогенних МБТ (M. tuberculosis, M. bovis, M. africanum) та умовно-патогенних атипових МБТ (M. avium, M. intracellulare, M. scrofulaceum) € їх висока кислотна, лужна та спиртова стійкість, внаслідок ліпідної фракції миколевої кислоти. За даними 3. Ваксмана (1943), первинна резистентна інформація вже була закладена в популяціях МБТ, які у 25,0 \% показали стійкість до стрептоміцину. Це підтверджено дослідами зразків ґрунту тих місць, де стрептоміцин та сучасні антибіотики ніколи не застосовувалися. Встановлено, що деякі бактерії передають свою стійкість через «ДНК-плазміду» своїм нащадкам, які стають не чутливими до призначених антибіотиків. Це спричинило появу та поширення бактерій, які майже не піддаються лікуванню наявними антибіотиками, так званих «супербактерій - superbug»: 1) метицилін-стійкий Staphylococcus aureus (MRSA); 2) пеніцилін-стійкий Streptococcus pneumoniae; 3) ванкоміцин-стійкий Enterococcus faecium; 4) карбепенемстійкий Pseudomonas aeruginosa; 5) кларитроміцин-стійкий Helicobacter pylori; 6) мультирезистентний та розширено резистентний туберкульоз (M-XDR) [4, 5].

Такий спосіб генної передачі стійкості до антибіотиків може відбуватися навіть між різними видами бактерій. При цьому резистентність уже існувала тисячі років ще до антибіотичної ери. Проте сам процес фрормування стійкості був запущений із появою перших антибіотиків і нині медикаментозна стійкість мікробів перетворилася на глобальну світову проблему.

Виходячи з наведеного, у світі залишається єдиний антибіотик тетрациклін, до якого ще не доведена стійкість бактерій. А з появою резистентності до макролідів можна прогнозувати, що через 17-20 років (20372040 рр.) людство стане беззахисним перед супербак- теріями, якщо не буде створено нового препарату, який підкорить ці «жахливі бактерії» [6].

Шляхи формування супербактерій. За даними звіту K. Okamoto (2015) з клініки Rush Чикагського університету, доведено, що основною причиною розповсюдження резистентних та мультирезистентних штамів в амбулаторних і госпітальних закладах є помилки лікарів та середнього медичного персоналу (Перша форма стійкості). Було зібрано 6000 зразків із 5000 місць навколо відділень інтенсивної терапії та досліджено руки, рукавички, халати медичних працівників до та після взаємодії з пацієнтом. Понад третини медичних працівників мали на собі бактерії з множинною медикаментозною стійкістю Staphylococcus aureus (MRSA), Enterococcus faecium. Орієнтовно 70 \% предметів (манжети кров'яного тиску, кнопки виклику, рейки ліжка), що контактували з пацієнтами були контаміновані супербактеріями. На думку звіту, такі помилки медичного персоналу підлягали легкому усуненню через введення суворого контролю за засобами щоденної дезінфекції палат, відділень інтенсивної терапії [4].

Друга форма стійкості. При неправильному застосуванні будь-яких антибіотиків може розвинутися не лише стійкість збудника, але й з'явиться медикаментозна залежність від призначеного антибіотика. Доведено, що під дією антибіотиків змінюється склад мікрофрлори в організмі людини. Частина збудників гине, деякі набувають стійкості, а інші стають залежними від препаратів. Тобто з'являються штами бактерій, ріст яких стимулюється тим або іншим антибактерійним препаратом. Причому в деяких випадках бактерії можуть рости лише в присутності цього вже необхідного для них хіміопрепарату. Таким чином, можна паралельно пояснити злоякісний варіант резистентності внутрішньогоспітальних мікробних штамів, грибів і вірусів, яких обробляють поширеними антисептиками та часто використовуваними шпитальними антибіотиками. Медикаментозна залежність мікобактерійної клітини, на яку лікар спрямовує антибактерійний препарат, стає агентом, що стимулює метаболізм і основні функції розмноження вже стійкої фрорми бактерійної інфекції. Найбільш небезпечними формами для пацієнтів є їх лікування після перерви, неефективна терапія після закінчення основного курсу, абацилярність і прогресування під час лікування, неадекватне застосування препаратів, до яких доведена стійкість, переривання курсу терапії, зловживання алкоголем та ко-інфекція ТБ/ВІЛ. Тоді в організмі пацієнта відбувається «селекція бактерій» найагресивніших видів, які вижили після хіміотерапії, і тепер вони починають швидко розмножуватися, продукуючи «супербактерії».

Синдром медикаментозної залежності необхідно диференціювати зі звичайними реакціями первинної 
стійкості до антибіотиків та реактивацією вторинного туберкульозного процесу. Залежність мікобактерій туберкульозу від антибактерійних препаратів $€$ негативним фактором, що різко знижує ефективність виліковування хворих на ТБ і обтяжує перебіг туберкульозного процесу. Продовження лікування антимікобактерійними препаратами при медикаментозній залежності бактерій $€$ надзвичайно шкідливим і має визнаватися протоколом як протипоказане!

Третя форма резистентності. У процесі лікування відбуваються мутації бактерій. Під впливом антибіотиків змінюються морфологічні, культуральні та біологічні властивості бактерій. Антибіотик, який діє на бактерію, впливає на метаболізм і спричиняє генні мутації. У певній ділянці молекули ДНК з'являється так звана вторинна резистентність. МБТ можуть персистувати в кокоподібні, зернисті та L-фрорми, зберігаючи свою патогенність десятками років. Повернення їх із персистування до патогенних називається реверсією. Саме в реверсії МБТ до хаотичного застосування антибактерійних препаратів за останні 70 років зародилася вторинна медикаментозна стійкість паличок Коха до стрептоміцину, фторхінолонів, аміноглікозидів, карбапенемів та інших. Визнано, що медикаментозна стійкість виникає шляхом «адаптації» МБТ до препаратів I ряду (S,H,R,E,Z). В умовах антимікобактерійної терапії відбуваються точкові хромосомні мутації зі змінами у рибосомно-матричній системі мікобактерій. Виявлено гени, мутація яких зумовлює стійкість до окремих протитуберкульозних препаратів. 3 другого боку, у кожній популяції чутливих до препаратів МБТ є 25 \% стійких мутантів, які в процесі лікування продовжують розмножуватися і їх популяція неухильно зростає. При неефективному лікуванні відбувається накопичення мутацій до окремих препаратів, що закріплюються в 2-3 генах. Таким чином, розвивається вторинна набута резистентність, яка з'являється через 1-2 міс. інтенсивного основного курсу лікування. Саме після одного місяця лікування вперше діагностованого хворого на туберкульоз слід робити розширені дослідження на вторинну резистентність, тому що у $75 \%$ лікованих хронічних хворих доведена поява такої стійкості.

Четверта форма резистентності. На сьогодні доведеним є фракт появи змішаної специфрічної інфекції (M. tuberculosis + S. aureus; M. tuberculosis + S. pneumoniae; M. tuberculosis + Aspergillus; M. tuberculosis +Acinetobacter; M. tuberculosis + Pseudomonas; M. tuberculosis/HIV1-2 та ін.), які нині стають критичними для людства. Пацієнти опиняються беззахисними перед змішаною специфічно-неспецифічною, грибковою та вірусною інфекцією. Супербактерії не є агресивніші від своїх родичів певного виду, вони комбінуються здебіль- шого в палатах інтенсивної та паліативної терапії. Саме там, де лікуються пацієнти з відкритими фрормами, ранами чи пролежнями, фрізично ослаблені та імунно виснаженні хворі. Відомо багато прикладів, коли через недотримання санітарного контролю супербактерії передаються від одного хворого до іншого, так звана «запозичена супербактерія». На жаль, нині лікарі майже вичерпали арсенал протимікробних препаратів і вимушені використовувати препарати резерву, наприклад фрторхінолони, оксазолідинони чи карбапенеми. Препарати резерву все частіше почали призначати для лікування грам-негативних іноекцій. За останнє десятиріччя бачимо появу ципрофлоксацин-резистентних штамів, різке збільшення кількості туберкульозних плевритів та емпієм плеври. Нагноєні плеврити пов'язані перш за все з невстановленою причиною ускладнень різноманітних за етіопатогенезом захворювань: 1) специфрічні (туберкульоз, актиномікоз, набутий імунодефіцит, ВІЛ-інфрекція), 2) неспецифрічні (парапневмонічні, параканкрозні, септичні, вірусні), 3) посттравматичні (згорнуті гемо- та пневмоторакси), 4) застійні (серцеві, післяопераційні) та ін.

Низький рівень діагностики саме туберкульозної емпієми плеври за наведеними категоріями породжує ще більше зростання резистентності МБТ при туберкульозі легень. «Специфрічність» туберкульозної емпієми плеври є достатньо умовним терміном, оскільки за даними клінічного перебігу в порожнині нагноєння завжди присутня змішана бактерійна грам-(+/-) мікрофрлора.

Раціональний вибір діагностики та хірургічного втручання значно зменшують формування резистентності при емпіємах плеври. Встановлення анатомічних локалізацій та патоморфологічних особливостей емпієми плеври, набутих бронхіальних нориць до стадії гнійного запалення потребує систематизації, індивідуалізації строків консервативного чи оперативного лікування, його характеру та об'єму. Клінічна картина реактивних інсеекційних емпієм плеври, як правило, починається поступово, а рідина в плевральній порожнині часто нагадує прояви пневмотораксу або виявляється при рентгенологічному дослідженні. Ексудат часто $€$ серозним 3 малою кількістю білка. Ступінь потовщення плеври говорить про давність випітного плевриту. Спеціальні дослідження дозволяють діагностувати палички МБТ в ексудаті. При торакоскопії виявляють випадання фрібрину, іноді з'являються туберкульозні горбики на поверхні плеври. Незначні ураження плеври МБТ, відсутність плевро-бронхіальних нориць, при масивній антибактерійній терапії (фрторхінолони, аміноглікозиди опосередковано діють на МБТ), як правило, закінчується розсмоктуванням рідини та облітерацією плеври. Проте, активність туберкульозного процесу в плеврі залиша- 
ється високою, і процес часто трансформується в туберкульозну емпієму плеври. За перебігом туберкульозні емпієми поділяються на: 1) безсимптомні, на кшталт холодного нагноєння, в легенях немає туберкульозних змін, а бронхо-плевральні нориці не розвиваються; 2) прогресуючі емпієми з яскравими змінами в легенях та наявністю бронхо-плевральних нориць; 3) рецидивні, які займають проміжне положення між безсимптомними і прогресуючими, нориць при рецидивних не буває, а загострення стану залежатиме від отриманого консервативного лікування та санації порожнин емпієм; 4) змішані туберкульозні емпієми, які супроводжуються тяжким перебігом внаслідок приєднання вторинного гнійного інфрікування. При змішаних емпіємах дуже швидко розвиваються дистрофічні зміни внутрішніх органів. Прогноз при таких фрормах дуже серйозний, процес може переходити в септичні стани. Це і $є$ власне суперінфекція туберкульозу, яку ми тепер все частіше виявляємо при генералізованих деструктивних фрормах. Лікування місцевого вогнища антибіотиками широкого спектру при септичних станах малоефективне і супроводжується швидким розвитком стійких форм збудника з явищами вираженої гнійно-резорбтивної гарячки. Клінічно це проявляється загальним виснаженням, пацієнт швидко втрачає вагу, знижується апетит, його часто лихоманить до 39-40 드. відбувається потовиділення, діарея, кашель 3 кровохарканням, нерідко кров'янистий кал, біль у грудях, задишка в спокої, лейкоцитоз зі значною лімфопенією, тромбоцитопенією, прискорення шОЕ до 50-70 мм/год. Процес при суперінсрекції може затягуватися до 6-20 тиж. Із 10 пацієнтів, яких ми спостерігали, лише 2 вижили, завдяки використанню комбінації тієнаму з протитуберкульозними препаратами в одного хворого та імуноглобуліну, переливання плазми та АМБП в другому випадку.

Більшість пацієнтів стають приреченими, які не в змозі перенести хірургічну операцію, спрямовану на ліквідацію нагноєння в грудній порожнині. Місцеві зміни в плеврі характеризуються проривом великих каверн у порожнину плеври, розпадом грануляцій, казеозно-некротичними виразками, септикопіємічними висипаннями на шкірі. Такі пацієнти гинуть дуже швидко, незважаючи на масивність комбінованої антибіотикотерапії. Ще дуже часто в таких хворих раніше ми бачили перенесені туберкульозні плеврити, що потребує окремого їх викладення.

Стадія фрібринозно-гнійного плевриту (II стадія емпієми плеври) починається тоді, коли ексудат у плеврі стає гнійним. У цей період запальні процеси розвиваються в судинному еластично-колагеновому шарі плеври: колагенові волокна розшаровуються білковою рідиною, яка багата фрібрином. 3'являється маса сег- ментоядерних лейкоцитів, на поверхні плеври серед фрібринозних мас виявляються скупчення лімфоцитів та еритроцитів. У цій стадії часто порушується поверхневий і, навіть, глибокий еластичний шар. Процес у цій стадії запалення чітко обмежений плевральним листком і не переходить на тканину легень, що відображено на фото 1 .

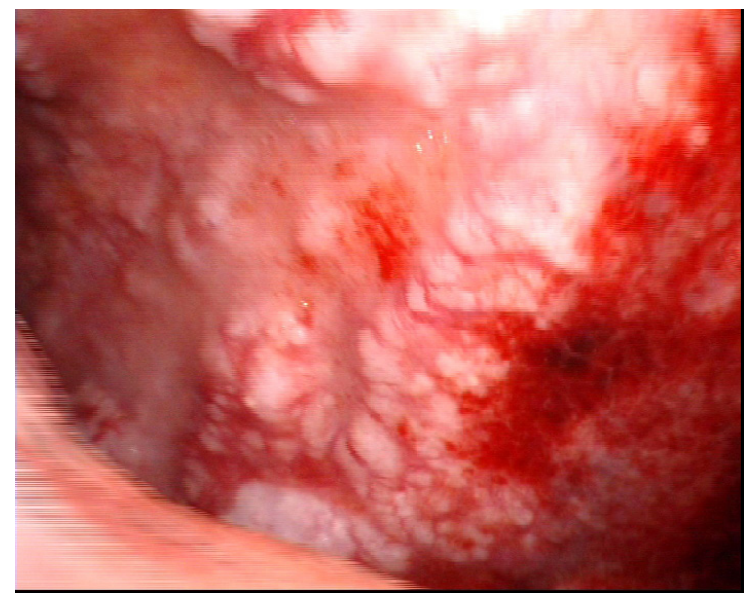

Фото 1. Фібринозно-гнійний плеврит, розростання сполучнотканинного колагенового шару, виявлені при торакоскопії хворого С., 54 р.

Стадія фрібринозно-гнійного запалення завжди свідчить про максимальний ступінь запальної реакції і залежить від збереження або припинення дії шкідливого «супербактерійного» агента. Тому при вивченні клінічної стадії емпієми визначальним фрактором переходу другої стадії в третю - репаративну $є$ не час, а стан основного вогнища інфекції.

Репаративна стадія (III стадія емпієми плеври) по суті не $є$ реакцією запалення, а наслідком організованої інфекції. Зазвичай інтенсивність відновних реакцій пропорційна ступеню передуючої руйнації тканин і появи так-званої «мертвої» субстанції в плевральній порожнині. Репаративну стадію емпієми називають стадією оформлення грануляційної тканини, яка часто починається на 30-45-у добу. Спочатку грануляційна тканина має вигляд тонкого прошарку з круглих голоядерних клітин, які розміщуються між пограничним шаром фрібринозно-гнійних нашарувань і збереженими шарами плеври. Потім у грануляціях починають дозрівати колагенові волокна. Сорормована грануляційна тканина утворює піогенну мембрану, яка з одного боку продукує гній, а 3 другого - відмежовує його від прилягаючих тканин. Таким чином організм пригнічує ріст і розмноження супербактерій.

Чіткого критерію переходу гострої емпієми в хронічну до сьогодні не встановлено. Перебіг гострої емпієми 
зазвичай триває 1-2 міс., проте цей період може затягуватися на триваліший час, але може й скорочуватися. Власне не строки запалення обумовлюють перехід гострої емпієми плеври в хронічну, а стан її стінок. Якщо у запальній зоні переважають альтеративно-ексудативні процеси, то навіть при довготривалому перебігу хвороби емпієму плеври слід розглядати як гостру. У цій стадії товщина стінок емпієми досягає 2-3 см, при цьому з боку парієтальної плеври стінка в 2 рази товстіша, ніж з боку вісцеральної плеври. Стінки емпіємного мішка ригідні, ущільнені, на внутрішній поверхні виявляються пласти фрібрину та гною до 5 мм завгрубшки. У стінці хронічної емпієми виявляються три шари: піогенний, рубцевий та шар власних тканин плеври. Вивчення морфрологічних особливостей плевральних зрощень залежно від строків їх утворення, а також можливості місцевого консервативного впливу на плевральні спайки та стінки емпіємної порожнини до нині зберігають свою актуальність (фрото 2).

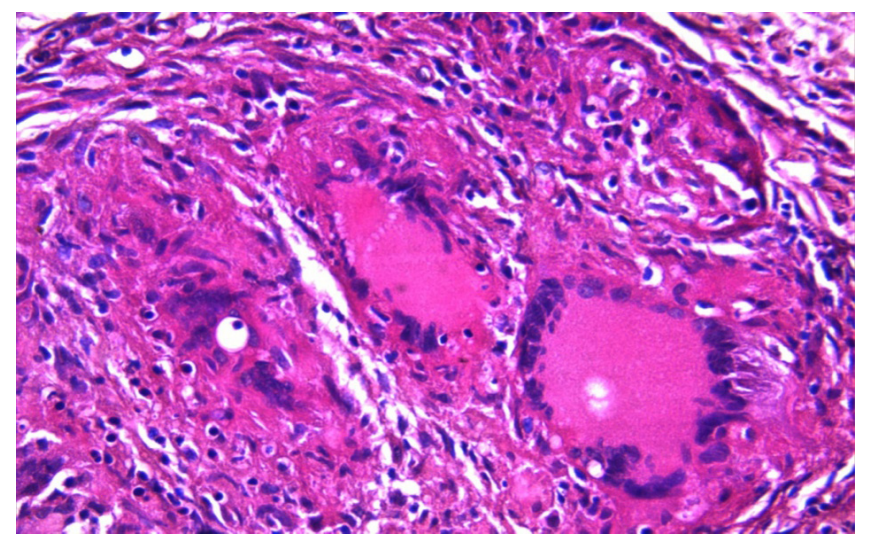

Фото 2. Гістофотограма туберкульозної емпієми плеври хворої О., 39 р. У центрі видно гігантські клітини ПироговаЛанганса, по периферії - розростання сполучної грануляційної тканини. Забарвлення гематоксилін-еозином, ×200.

Утворення нориць. На практиці найчастіше трапляються плевро-легеневі нориці, рідше - плевро-торакальні. Можливі два механізми утворення плевробронхіальної фрістули: 1) прорив парієтального туберкульозного вогнища чи каверни з легені в плевру; 2) при казеозному некрозі туберкульозного горбика по плеврі в легеню. У результаті прориву горбиків утворюється вузька щілина між плеврою, альвеолярними ходами та дрібними бронхами. При глибоких казеозних некрозах, значному ураженні плеври утворюються ширші нориці між плеврою та більшими бронхами. Найбільші нориці утворюються при відкритті каверни в порожнину плеври. Таким чином бронхи, які дренують каверну, перетворюються у власне бронхіальні нориці. Дуже часто казеозні маси каверни закривають вустя нориці, але при лізисі сирнистого некрозу нориці продовжують фрункціонувати. У тканинах норицевих ходів практично завжди знаходяться специфічні туберкульозні елементи у вигляді епітеліоїдно-клітинних гранульом. Ці гранульоми завжди є запальними, лише механічне хірургічне видалення сприяє процесу їхнього рубцювання та загоєння.

Небезпеку супербактерій вперше діагностованого туберкульозу можна продемонструвати на прикладах розвитку туберкульозного перитоніту.

Випадок 1. Пацієнт І.С., 54 роки, який протягом 3 міс. отримував інтенсивну фразу лікування з 4 АМБП $(H+R+E+Z)$ у фотизіатричному відділенні обласного протитуберкульозного диспансеру з приводу ВДТБЛ (2019) легень (дисемінований) фраза інфільтрації. Дестр. +, МБТ +, M +, K+, гіст. 0, резист. -. Ускладнення: розлитий гнійно-фрібринозний перитоніт, перфрорація антрального відділу шлунка, гіст. +, Кат. 1, Ког. 2. Наприкінці інтенсивної фрази лікування (3 міс.) хворому проведено ретнген-контроль грудної порожнини і виявлено вільний газ під куполами діафрагми. Пацієнт був оглянутий хірургом і ургентно прооперований з діагнозом «Розлитий туберкульозний перитоніт, зашивання перфоративної виразки шлунка». Післяопераційний період перебігав з ускладненням у вигляді двобічного випітного плевриту, який було ліквідовано додатковими пункціями. Хворий отримував масивну довенну протитуберкульозну терапію фрторхінолонами та макролідами, рана зажила первинним натягом. Макропрепарат туберкульозного ураження шлунка відображено на фрото 3.

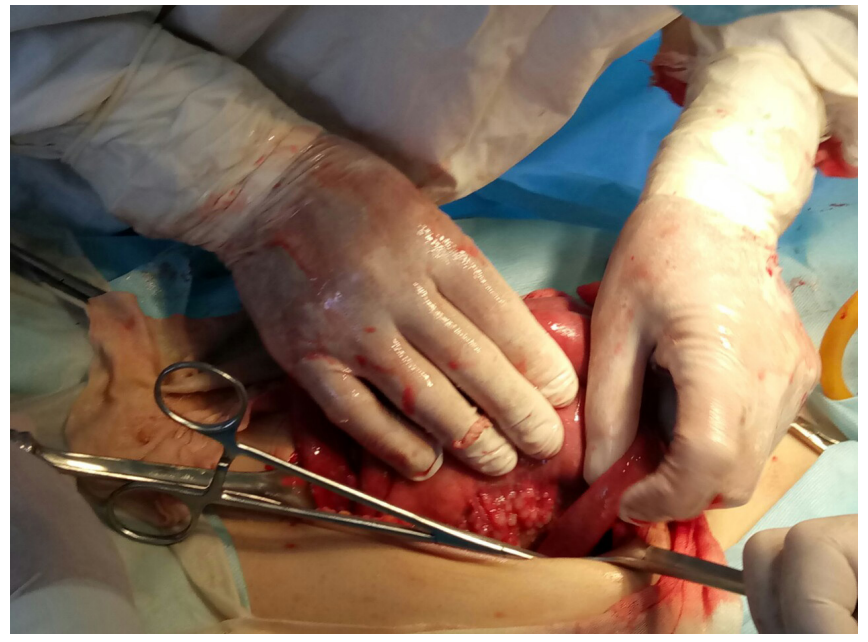

Фото 3. Оперування пацієнта І.С., 54 р., з приводу туберкульозного перитоніту з перфорацією шлунка внаслідок розпаду специфічної гранульоми. 
Пацієнт був виписаний на амбулаторне лікування додому на підтримуючу фразу (ізоніазид 0,3; рифрампіцин 0,6), після чого помер до 1 міс. від прогресування генералізованого дисемінованого супертуберкульозу легень із розпадом та туберкульозного перитоніту із перорорацією шлунка. На 2-у міс. лікування у хворого проявилася друга фрорма резистентності - медикаментозна залежність від призначеного лікування. Пацієнту було продовжено інтенсивну фразу до 90 доз тими ж препаратами і було отримано фрінальний результат тотальної резистентності у вигляді розлитого перитоніту з перфорацією шлунка.

Випадок 2. Пацієнтка О.Г., 37 років, переведена 3 2-ї міської лікарні після проведеної операції верхньонижньої лапаротомії з приводу розлитого гнійного туберкульозного перитоніту, множинні перфоративні виразки тонкої кишки; резекції до 60 см тонкої кишки із виведенням ентеростоми. Діагноз: Ко-інфекція СНІД, IV клінічна стадія, виражена імуносупресія CD4 $4^{+}<50$ кл/ мл / ВДПТБ (2018) туберкульоз кишечнику з перфорацією тонкої кишки. Дестр +, МБТ +, М +, Гіст. +. Резист. -. Операція: резекція тонкої кишки з ентеростомою. Макропрепарат туберкульозного ураження кишечнику відображено на фрото 4.

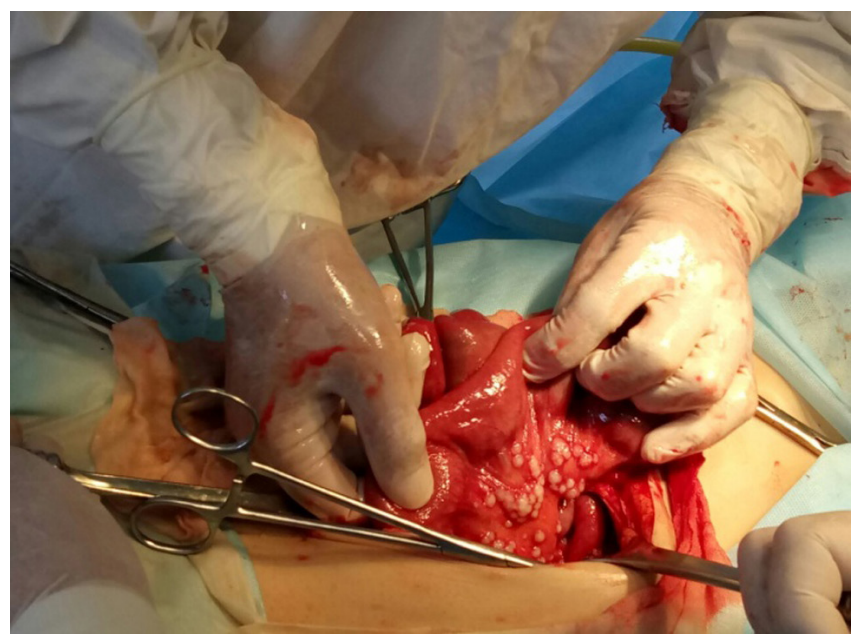

Фото 4. Оперування пацієнтки О., 37 р., з приводу розлитого гнійно-фрібринозного перитоніту з множинними перфораціями тонкої кишки.

Післяопераційний період перебігав до 14 діб сприятливо, післяопераційна рана зажила первинним натягом на фроні прийому меронему, фрторхінолонів, ізоніазиду, інбутолу внутрішньовенно, канаміцину внутрішньом'язово, піразинаміду орально. Починаючи від 15-ї доби, відбулося прогресування туберкульозу у вигляді гнійного перитоніту, розходження загоєної рани, евентрація органів, прогресування серцево-су- динної та печінково-ниркової недостатності. Пацієнтка померла, незважаючи на масивну антибіотикотерапію, протитуберкульозну та імунокоригувальну терапію, від прогресування суперінфрекції ВІЛ/ТБ - т.з. четверта змішана форма резистентності.

Як видно з наведених прикладів, в Україні вже давно спостерігаються різні види прихованої суперінфекції МБТ, які в попередніх експрес-тестах проявилися як вперше діагностовані випадки дисемінованого туберкульозу та вперше діагностованого позалегеневого туберкульозу з чутливістю до ізоніазиду та рифампіцину.

Постає просте запитання: як бути, що робити та як лікувати? На ці запитання ні ВОО3, ні ООН однозначної відповіді дати не можуть. Глобальна система нагляду за антимікробною стійкість GLASS - перше спільне зусилля для сприйняття спостереження резистентності обраних бактерій, що викликають гострі інорекції: Acinetobacter spp., Escherichia coli, Klebsiella pneumoniae, Streptococcus pneumonia, Salmonella spp., Shigella spp., Neisseria gonorrhaeae. Започатковано ВООЗ у 2015 р., і станом на грудень 2018 р. залучено до участі вже 71 країну.

У світі зростає розуміння необхідності виконання саме загальних дій держав для подолання резистентності до антибіотиків. Найновішим документом, що фокусується на проблемі боротьби із резистентністю, став звіт Генерального секретаря ООН, оприлюднений у квітні 2019 р. Основне положення цього документу таке: «... оскільки фрактори, що підсилюють резистентність до протимікробних препаратів, пов'язані з людиною, тваринами, рослинами, харчовими продуктами і навколишнім середовищем, виникає необхідність впровадження чітких заходів у рамках "єдиної концепції охорони здоров'я", що буде спрямована на залучення всіх зацікавлених сторін та їх об'єднання на основі загального бачення та цілей» [5]. Ситуація з резистентністю в Україні, на жаль, є рівнянням з багатьма невідомими через відсутність достовірних, коректних, стандартизованих і проаналізованих даних. Тож ми досі не стали учасниками цього глобального GLASS процесу ВОO3 [6].

Безвихідних ситуацій в природі не буває. Вихід, на наш погляд, необхідно шукати саме в епідемічному процесі вакцинації та ревакцинації BCG. Популярною стала вакцинація хворих на туберкульоз бацилою КальметтаГерена (BCG, 1921). Вакцина містить живі мікобактерії вакцинного штаму M. bovis. Розмножуючись в організмі після щеплення, МБТ фрормують тривалий та стійкий захист від туберкульозу та інших бактерій. Вироблення антитіл до стійких штамів мікобактерій триває до тих пір, поки імунній системі щепленого пацієнта презентується мікобактерійний суперантиген, і іноді це триває 
роками. Проте неспецифічністъ лікувальної дії не вивчена, а складність дозування та оцінки лікування змусили багатьох дослідників у світі відмовитися від застосування BCG на користь вакцин, що містять специфрічний стійкий антиген та ефективні імуностимулятори. Разом 3 цим, ще трапляються дослідження, в яких науковці підтримують цю думку. На вироблення нової супервакцини від тотально резистентного туберкульозу (XXDR) у світі часу залишається мало!

Другою альтернативою $є$ бактеріофаги - віруси, які вбивають бактерії. Їх називають «пожирачами бактерій». щоправда, ця назва вводить всіх в оману, оскільки бактеріофраги не пожирають бактерії, а паразитують на них для виживання і поширення серед інших патогенних бактерій. Бактеріофраги були відкриті ще у 1915 р., а під час II Світової війни використовувалися хірургами для лікування гангрени кінцівок. Вони можуть передавати молекулярно-генетичну інфрормацію супербактеріям і перетворювати їх знову у непатогенні.

Сьогодні вчені знову почали вивчати бактеріофаги як альтернативу антибіотикам. Іх здатність перетравлювати бактерії, а особливо резистентні, залежить від стану макроорганізму, віку, статі, спадкових фракторів, вірулентності та кількості народжених осіб. Схильність до туберкульозу корелює з такими антигенами головного комплексу гістосумісності (HLA), як DR2, B7, B14. Роль клітинно-гуморального імунітету при туберкульозі досі остаточно не з'ясована. Так що майбутнє людства має залежати від успіхів вакцинації, генної інженерії та імунології.

\section{Висновки}

1. Фено- та генотипна культивація мікобактерій зумовлює їх резистентність до більшості препаратів, особливо II ряду (левофрлоксацину, моксифлоксацину, лінезоліду).

2. Покращення експрес-діагностики дає можливість диореренціювати синдром медикаментозної залежності МБТ з реакціями стійкості до препаратів І ряду (ізоніазид і рифрампіцин) та інших антибіотиків, які необхідно відстежувати після 1-го міс. лікування.

3. Соціальна профрілактика та жорсткі кроки стосовно виліковування пацієнтів з усіма фрормами туберкульозу будуть пригнічувати джерело резистентної інфекціï.

4. Необхідна негайна відміна в державі програми амбулаторного безконтрольного лікування пацієнтів протитуберкульозними препаратами.

5. Контрольоване виписування аптечних антибіотиків, поведінкова мотивація населення та відмова від застосування антибіотиків у тваринництві та сільському господарстві повинні стати догмою порятунку людини від інфекції.

\section{Література}

1. Фещенко Ю.І. Неесективне лікування хворих на туберкульоз легень і його попередження / Ю.І. Фещенко, В.М. Мельник, М.С. Опанасенко. - Київ, 2019. - С. 91-105.

2. Фещенко Ю.І. Суперінфекції: чи достатньо у людства зброї для їх подолання / Ю.І. Фещенко, М.І. Гуменюк // Інфрузія \& Хіміотерапія. - 2019. - № 1. - С. 3-8.

3. Frieden T. Toman's tuberculosis case detection, treatment, and monitoring: questions and answers / Ed. by T. Frieden. -2 nd ed. Geneva: WHO, 2016. - 406 p.

4. Bad bugs, no drugs: no ESKAPE! An update from the infections Diseases Society of America / H. W. Boucher, G. H. Talbot, J. S. Bradley [et al.] // Clinical Infections Diseases. - 2009. - Vol. 48, N 1. - P. 1-12.

5. WHO methodology for point prevalence survey on antibiotic use in hospitals (No. WHO/EMP/IAU/2018.01) / World Health Organization. -2018

6. Global tuberculosis report. Geneva: WHO, 2018. - 243 p.

\section{References}

1. Feshchenko, Yu.I., Melnyk, V.M., \& Opanasenko, M.S. (2019). Ineffective treatment of patients with pulmonary tuberculosis and its prevention [in Ukrainian].

2. Feshchenko, Yu.I., \& Humeniuk, M.I. (2019). Superinfections: Do humans have enough Weapons to overcome? Infusion \& Chemotherapy, (1), 3-8 [in Ukrainian].

3. Frieden, T. (2016). Toman's tuberculosis case detection, treatment, and monitoring: questions and answers. edited by T. Frieden. $2^{\text {nd }}$ ed. Geneva: WHO.

4. Boucher, H.W., Talbot, G.H., Bradley, J.S., Edwards, J.E., Gilbert, D., Rice, L.B., ... \& Bartlett, J. (2009). Bad bugs, no drugs: no ESKAPE! An update from the Infectious Diseases Society of America. Clinical Infectious Diseases, 48 (1), 1-12.

5. World Health Organization (2018). WHO methodology for point prevalence survey on antibiotic use in hospitals (No. WHO/EMP/ IAU/2018.01). World Health Organization.

6. World Health Organization (2018). Global tuberculosis report. Geneva: WHO. 


\section{PROBLEM OF SUPERINFECTIONS: WORLD THREAT OF DEATH OR POSSIBILITY OF ITS GLOBAL OVERCOMING?}

\author{
Yu.F. Koshak \\ I. Horbachevsky Ternopil National Medical University
}

SUMMARY. According to WHO, in 2017, 10.4 million of patients fell ill with tuberculosis, $47 \%$ of patients became infected with multi drug resistance for antimycobacterial drugs, and $1.7 \mathrm{mln}$. of them died. Each year, they record up to 700 thousand deaths from infectious diseases in the field of Pulmonology: COPD, bronchial asthma, atypical pneumonia, and interstitial lung diseases. Generalized septic infections with suppuration, corona viruses cause mutations of microorganisms to the antibacterial drugs and form drug resistance.

The aim of the study - to improve early diagnosis of drug-resistant superbacteria and interrupt the ways of its formation through molecular technological methods. An overview of the data showed the need for improvement in medical institutions of early diagnosis of superinfections, which will warn the formation of extended resistance of microorganisms to antibacterial drugs. The high rate of formation of resistance of bacteria now have ahead of the introduction of new antimicrobial agents, which poses a threat to an ageing population of the planet. Due to the resistance of microorganisms, mixed specific and non-specific flora to the main drugs worldwide, there is the emergence of global disease with superinfection, which is caused by "superbacteria - nightmarebacteria - Superbug". Due to the low level of modern molecular diagnostics this level of "superinfections" is hidden and the quantity is significantly understated. In the absence of effective global steps to reduce the rate of resistance to microorganisms, the planet's population by 2050 may decrease by 10 million people per year, due to reactivation of atypical pneumonia, secondary tuberculosis (TB), expansion on the planet of total resistant tuberculosis (XXDR).

Conclusions. The introduction of modern moleculargenetic technologies will allow accurately establishing the etiology process, to conduct the identification of mycobacteria and microorganisms and to determine the phenotymetric and genotytypical sensitivity of bacteria to Antimycobacterial drugs. Such diagnostics will promote effective treatment of patients who are already infected with persistent strains of bacteria.

Key words: superinfection; tuberculosis; mycobacterium; antimycobacterial drugs; absolute resistance.

\section{Відомості про автора:}

Кошак Юрій Феодосійович - к. мед. н., асистент кафредри пропедевтики внутрішньої медицини та фртизіатрії Тернопільського національного медичного університету імені І.Я. Горбачевського; e-mail: koshak.yuriy@gmail.com

ORCID ID: https:/orcid.org/0001-6512-0255

Information about the autor:

Koshak Yu. F. - PhD, Assistant Professor of Internal Medicine Propaedeutics and Tuberculosis Department, I. Horbachevsky Ternopil National Medical University; e-mail: koshak.yuriy@gmail.com

ORCID ID: https:/orcid.org/0001-6512-0255

Конфрлікту інтересів немає.

The author has no conflicts of interest to declare.

Отримано 18.12.2020 р. 